\title{
Glycoalkaloids of Solanum Series Megistacrolobum and Related Potato Cultigens
}

\author{
TIMOTHY JOHNS* and STANLEY F. OSMAN ${ }^{+}$
}

Division of Biological Sciences, University of Michigan, Ann Arbor, MI 48109, U.S.A.; tEastern Regional Research Center, ARS, USDA, Philadelphia, PA 19118, U.S.A

\begin{abstract}
Key Word Index-Solanum Series Megistacrolobum; Solanum $\times$ ajanhuiri; Solanaceae; potato; Bolivia; glycoalkoloids; domestication.

Abstract-Glycoalkaloids were used as evidence of the affinities of nine taxa of Solanum Series Megistacrolobum and related potato cultigens from western Bolivia. S. boliviense, $S$. sanctae-rosae and $S$. toralapanum contain the commertetraose sugar moiety and appear to represent a relatively wild group within the Series. $S$. megistacrolobum, $S$. sogarandinum and $S$. raphanifolium show anomolous glycoalkaloid profiles that probably reflect hybridization associated with human disturbance. Primitive forms of the $S . \times$ ajanhuiri cultigen are indistinguishable chemically from conspecific weeds that were previously classified as $S$. megistacrolobum. Variation in total glycoalkaloid content within Series Megistacrolobum likely reflects direct selection by humans for reduced glycoalkaloid levels during the domestication process.
\end{abstract}

\section{Introduction}

Solanum megistacrolobum Bitt. is among the most frost-resistant potato species and is reputedly well adapted to arid conditions $[1,2]$. The natural introgression of genes of $S$. megistacrolobum into the cultivated gene pool via the cultigen $S$. $\times$ ajanhuiri Juz. et Buk. has been important for extending the range of potato cultivation by Aymara-speaking farmers into the frigid and arid areas of western Bolivia. On the other hand populations of $S$. megistacrolobum have received genes from cultivated species through introgression; the nature of wild potatoes reflects human disturbance associated with the domestication process $[3,4] . S$. megistacrolobum, in particular, is a highly variable species $[1,5]$. In general, discontinuities within the Series Megistacrolobum are difficult to delineate and make taxonomic decisions problematic. Surveys of steroidal glycoalkaloid constituents of wild species of tuber-bearing Solanum have neglected Series Megistacrolobum [6-8]. Chemotaxonomic information was expected to given new insight into interspecific affinities

\footnotetext{
*Present address: Department of Entomological Sciences, University of California, Berkeley, CA 94720, U.S.A.
}

(Received 14 August 1985) within the Series Megistacrolobum, as well as the origins of the cultigen, $S . \times$ ajanhuiri.

The ready hybridization of $S$. megistacrolobum and the diploid cultigen $S$. stenotomum Juz. et Buk. indicates that $S$. megistacrolobum may have excellent potential in potato breeding. Assessment of glycoalkaloid content, in itself, is important for determining the suitability of wild species in breeding programs [9].

\section{Results and Discussion}

Structural relationships of aglycones and glycoalkaloids identified in this study are recorded in Figure 1. Glycoalkaloid analyses of S. megistacrolobum (Table 1) are consistent with the morphological variability typical of this species. Accessions obtained from the Potato Introduction Station, Sturgeon Bay, were characterized by tomatine (12), with some accessions also containing demissine (6) as either the major or minor constituent.

Accession PI320303 contained commersonine (7), 6 and trace amounts of 12. It closely resembled P1458397, identified as $S$. toralapanum Card. et Hawkes, in both glycoalkaloid constituents and leaf morphology. Both collections were made in the southern part of the range of these species. Ochoa [10] has recently reduced $S$. toralapanum (referred to 


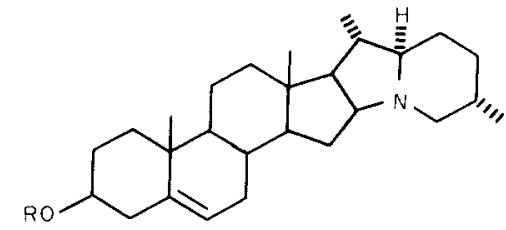

$1 \mathrm{R}=\mathrm{H}$; solanidine

$2 \mathrm{R}=0$-Glc- $(1 \rightarrow 3)-[\mathrm{Rha}-(1 \rightarrow 2)]-\mathrm{Gal} ; \alpha$-solanine

$3 \mathrm{R}=0$-diRha- $(1 \rightarrow 2,1-4)$-Glc; $\alpha$-chaconine

$4 \mathrm{R}=0$-diGlc- $(1 \rightarrow 2,1 \rightarrow 3)$-GIc- $(1-4)$-Gal; dehydrocommersonine

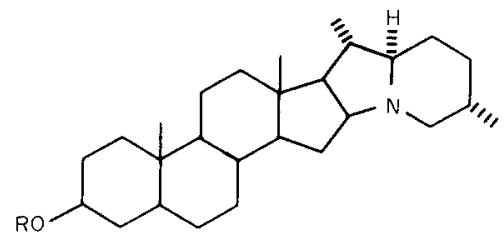

$5 \mathbf{R}=\mathrm{H}$; demissidine

$6 \mathrm{R}=0-\mathrm{Xyl}-(1 \rightarrow 3)-[\mathrm{Glc}(1 \rightarrow 2)]-\mathrm{Glc}-(1-4)-$ Gal; demissine

$7 \mathrm{R}=0$-diGlc- $(1 \rightarrow 2,1 \rightarrow 3)$-Glc- $(1 \rightarrow 4)$-Gal; commersonine

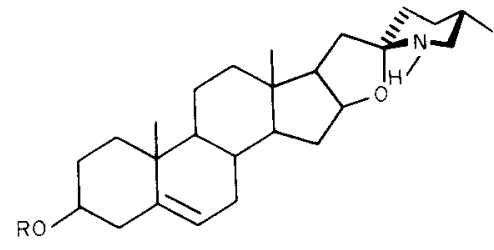

$8 \mathrm{R}=\mathrm{H}$; tomatidenol

$9 \mathrm{R}=0$-Glc- $(1 \rightarrow 3)-[$ Rha $(1 \rightarrow 2)]-\mathrm{Gal} ; \alpha$-solamarine

$10 \mathrm{R}=0$-diRha- $(1 \rightarrow 2,1 \rightarrow 4)-\mathrm{Glc} ; \beta$-solamarine

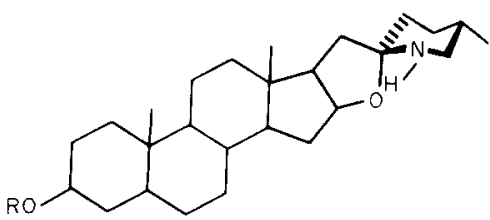

$11 \mathrm{R}=\mathrm{H}$; tomatidine

$12 \mathrm{R}=0-\mathrm{Xyl}-(1 \rightarrow 3)-[\mathrm{Glc}(1 \rightarrow 2)]-\mathrm{Glc}-(1-4)$-Gal; tomatine

$13 \mathrm{R}=0$-diGlc- $(1 \rightarrow 2,1 \rightarrow 3)-\mathrm{Glc}-(1 \rightarrow 4)$-Gal; sisunine

FIG. 1. STRUCTURAL RELATIONSHIPS OF GLYCOALKALOIDS AND AGLYCONES IDENTIFIED IN THIS STUDY.

here as taxon toralapanum) to a synonym of $S$. megistacrolobum. Two field collections of taxon toralapanum from the Department of La Paz, Bolivia, were, like the more southern accessions, characterized by the commertetraose

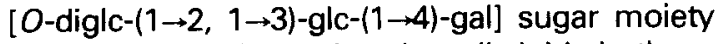
(14). However, the major glycoalkaloids in these plants were dehydrocommersonine (4) and 6.
Glycoalkaloid patterns in the Series Megistacrolobum (Table 2) are closer across species lines than within $S$. megistacrolobum (sensu lato) alone (Table 1) and show distinct geographical patterns. $S$. boliviense Dun. (PI310974 and PI310975) has a glycoalkaloid profile very similar to Pl458397 (taxon toralapanum). S. sanctae-rosae Hawkes (PI205397 and PI218221) from Argentina is similar to PI320303 from Argentina, as well as having affinity to its Bolivian relatives, $S$. boliviense and taxon toralapanum.

Peruvian species assigned to Series Megistacrolobum stand out chemotaxonomically. S. raphanifolium (PI310951 and PI310999) from the Department of Cuzco contained $\alpha$ solanine (2) and $\alpha$-chaconine (3) exclusively. These glycoalkaloids are characteristic of other series in the genus including the cultigen containing Series Tuberosum; S. raphanifolium may be misplaced in Series Megistacrolobum or may show introgression from Series Tuberosum via the cultivated gene pool.

$S$. sogarandinum (PI230510) from northcentral Peru was characterized by the $\alpha$ - (9) and $\beta$ - (10) solamarines. This unique glycoalkaloid pattern of $S$. sogarandinum resembles the trace glycoalkaloids that typify populations of wild potato from north-west Bolivia (Table 2: weed $S . \times$ ajanhuiri). S. sogarandinum shows clear morphological affinities to these populations [5] and may be simply an isolate from them. Dispersal of $S$. sogarandinum to northern Peru may reflect the association of $S$. sogarandinum and related Bolivian populations of this taxon with domesticated potatoes and their human cultivators. The Bolivian populations, while previously classified as $S$. megistacrolobum are, in fact, conspecific weeds of the cultigen, $S$. $\times$ ajanhuiri [11]. These weeds are indistinguishable taxonomically [11] and chemically (Tables 1 and 2) from yari cultigens of $S . \times$ ajanhuiri that are reputedly $F 1$ hybrids between $S$. megistacrolobum $(2 n)$ and the diploid cultigen $S$. stenotonum $[2,12]$. Ajawiri clones have been demonstrated to be backcrosses with S. stenotonum [12]. Clones of ajawiri and $S$. stenotonum studied here are identical to those studied previously; both contain (2) and (3) [7] (Table 3).

Total glycoalkaloids (TGA) varied consider- 
TABLE 1. GLYCOALKALOIDS OF SOLANUM MEGISTACROLOBUM SENSU LATO, INCLUDING TAXON TORALAPANUM AND WEEDS OF S. $\times$ AJANHUIRI

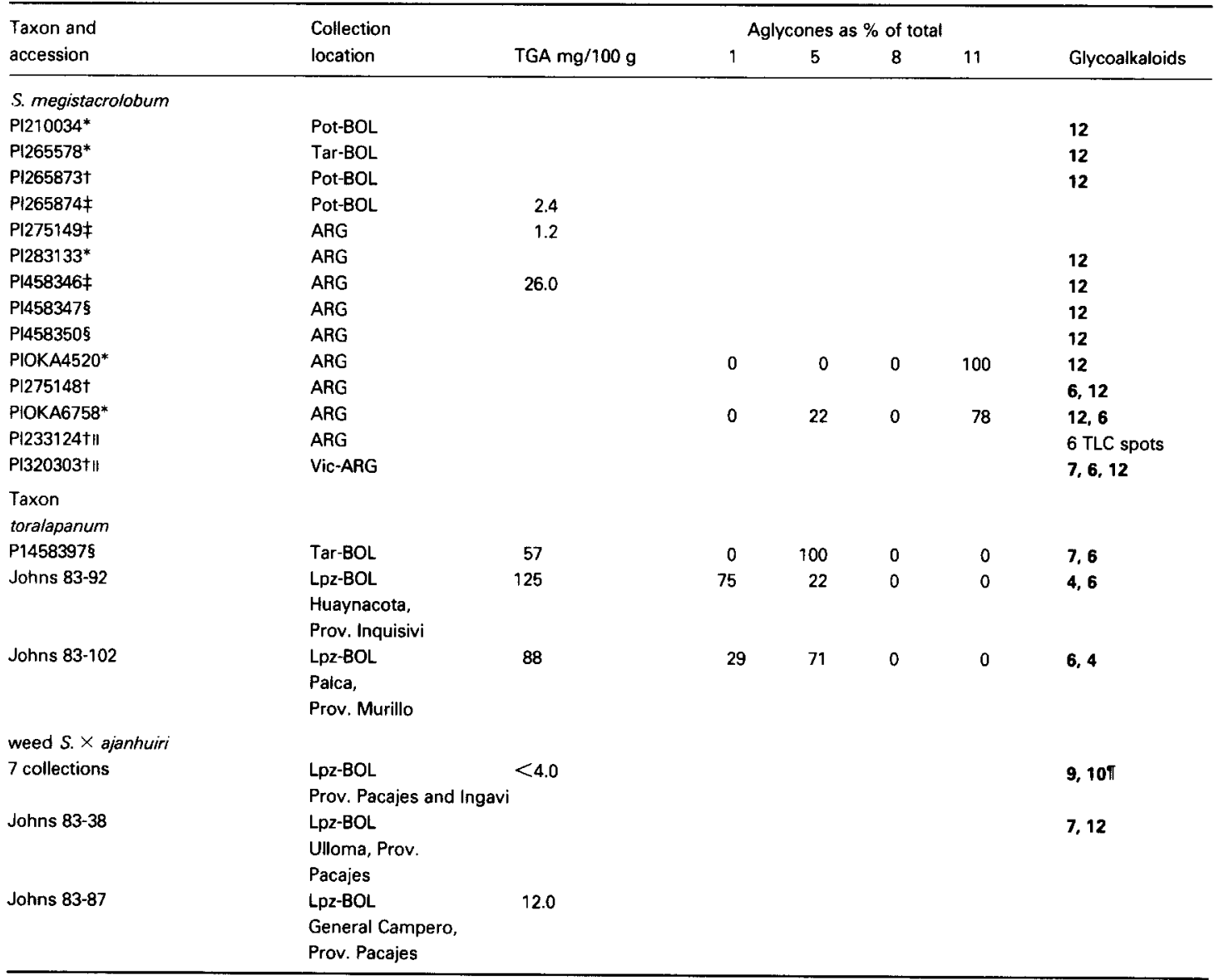

‡Tubers grown at Matthaei Botanical Gardens.

STubers from Potato Introduction Station.

*Vegetative material grown at Mattaei Botanical Gardens.

tRhizomes grown at Mattaei Botanical Gardens.

ILeaf morphology similar to taxon toralapanum.

TBest guess on basis of co-chromatography with other standards.

Departmental codes: Pot, Potosi; Tar, Tarija; Vic, San Victoria; Lpz, La Paz. Country codes: BOL, Bolivia; ARG, Argentina.

ably within the material studied. Differences in TGA between field collected and greenhousegrown material and between large and small tubers make comparisons using TGA content difficult. However, it is apparent that wild species have higher levels of TGA than cultigens and conspecific weeds.

We have recently described the glycoalkaloids of the cultivated clones, sisu [13]. Sisu, designated taxonomically as $S$. acaule $\times$ ajanhuiri, contains 7 and the novel hybrid glycoalkaloid, sisunine (13). The commertetraose moiety (14) in this cultigen supports its derivation from Series megistacrolobum ancestors. TGA content of sisu clones reported here reflect the intermediate nature of sisu between low TGA containing $S . \times$ ajanhuiri cultigens and high TGA containing $S$. acaule Bitt. (Series Acaule) [7].

The interactions of Series Megistacrolobum and cultivated potatoes is most apparent in the highly variable $S$. megistacrolobum and $S . \times$ 
TABLE 2. GLYCOALKALOID CHARACTERIZATION OF ACCESSIONS OF SERIES MEGISTACROLOBUM OBTAINED FROM POTATO INTRODUCTION STATION, STURGEON BAY, WISCONSIN

\begin{tabular}{|c|c|c|c|c|c|c|c|}
\hline \multirow{2}{*}{$\begin{array}{l}\text { Species and } \\
\text { accession }\end{array}$} & \multirow{2}{*}{$\begin{array}{l}\text { Collection } \\
\text { location }\end{array}$} & \multicolumn{6}{|c|}{ Aglycones as $\%$ of total } \\
\hline & & $\mathrm{TGA} \mathrm{mg} / 100 \mathrm{~g}$ & 1 & 5 & 8 & 11 & Glycoalkaloids \\
\hline \multicolumn{8}{|l|}{ S. boliviense } \\
\hline $\mathrm{Pl} 1310974$ & $\mathrm{BOL}$ & 72 & 11 & 89 & 0 & 0 & $7,6^{x}$ \\
\hline $\mathrm{P} \mid 310975$ & $\mathrm{BOL}$ & 61 & 10 & 90 & 0 & 0 & $7,6^{*}$ \\
\hline \multicolumn{8}{|c|}{ S. raphanifolium } \\
\hline $\mathrm{P} \mid 310951$ & Cuz-PER & 37 & 100 & 0 & 0 & 0 & $3,2^{*}$ \\
\hline $\mathrm{P} \mid 310999$ & PER & 28 & 100 & 0 & 0 & 0 & $3,2^{*}$ \\
\hline \multicolumn{8}{|c|}{ S. sanctae-rosae } \\
\hline $\mathrm{Pl} 205397$ & ARG & 20 & & & & & $6,7,12^{*}$ \\
\hline $\mathrm{PI} 218221$ & Tac-ARG & 25 & 8 & 75 & 0 & 17 & $6,7,12^{*}$ \\
\hline \multicolumn{8}{|c|}{ S. sogarandinum } \\
\hline $\mathrm{PI} 230510$ & Lib-PER & 28 & 0 & 0 & 100 & 0 & 9,10 \\
\hline
\end{tabular}

*Traces of glycoalkaloids with aglycone 2 .

Country codes: BOL. Bolivia; PER, Peru; ARG, Argentina. Department Codes: Cuz, Cuzco; Tac, Tacuman; Lib, Libertad.

TABLE 3. GLYCOALKALOIDS OF CULTIGENS OF SOLANUM $\times$ AJANHUIRIAND S. STENOTONUM

\begin{tabular}{|c|c|c|c|c|c|c|}
\hline \multirow{2}{*}{$\begin{array}{l}\text { Species and } \\
\text { clone identity }\end{array}$} & \multicolumn{6}{|c|}{ Aglycones as $\%$ of total } \\
\hline & $\mathrm{TGA} \mathrm{mg} / 100 \mathrm{~g}$ & 1 & 5 & 8 & 11 & Glycoalkaloids \\
\hline \multicolumn{7}{|l|}{ S. $\times$ ajanhuiri } \\
\hline ajawiri & $10.5-$ & 100 & 0 & 0 & 0 & 2,3 \\
\hline (two clones) & 13.0 & & & & & \\
\hline yari & $<4.3$ & & & & & $9,10^{*}$ \\
\hline \multicolumn{7}{|c|}{ (six collections of three } \\
\hline \multicolumn{7}{|c|}{ clones: Y1, Y2, Y5 [2]] } \\
\hline S. stenotomum & 11.3 & 100 & 0 & 0 & 0 & 2,3 \\
\hline (three clones) & 20.8 & & & & & \\
\hline S. acaule $X$ ajanhuiri & $12.0-$ & 0 & 55 & 0 & 45 & 7, 13 \\
\hline sisu & 24.8 & & & & & \\
\hline (three clones) & & & & & & \\
\hline
\end{tabular}

*Best guess on the basis of co-chromatography with other standards.

All analyses were made on tubers collected in the Departments of La Paz and Oruro, Bolivia.

ajanhuiri. S. sogarandinum and S. raphanifolium, as well, are commonly found as weeds in crop potato fields [5]. All of these species are apparently involved in reticulate hybridization among wild species and between wild and cultivated species. Human influence takes the form of habitat disturbance and plant dispersal. As well, glycoalkaloid content in Series Megistacrolobum likely reflects direct selection by humans resulting in reduction in TGA levels during the domestication process. Taxon toralapanum, S. boliviense and S. sanctae-rosae appear, on the basis of 14 , to represent a cohesive unit within the Series. The high TGA levels in taxon toralapanum and $S$. boliviense suggests that they are relatively wild. The characteristic of generally simple leaves shared by these two taxa [1] may represent a primitive condition of the Series Megistacrolobum before the onset of domestication.

\section{Experimental}

Material designated by PI accession numbers was obtained from the Potato Introduction Station, Sturgeon Bay, Wisconsin, as tubers or seeds. Seeds were grown at the Matthaei Botanical Gardens, University of Michigan, to obtain leaf and rhizome material. Material was freeze-dried and stored at $-10^{\circ}$. Field collections of $S$. megistacrolobum, $S . \times$ ajanhuiri, $S$. acaule $\times$ ajanhuiri and $S$. stenotomum were made in Bolivia. Vouchers are deposited in the University of Michigan Herbarium. Tubers were preserved in $95 \% \mathrm{EtOH}$ at room temperature.

All samples were extracted exhaustively in $5 \%$ methanolic HOAC. Ethanolic extracts were concd to dryness and tubers 
were re-extracted with acidic $\mathrm{MeOH}$. Extracts were concd to dryness, taken up in $0.1 \mathrm{~N} \mathrm{H}_{2} \mathrm{SO}_{4}$ and precipitated with concd $\mathrm{NH}_{4} \mathrm{OH}$.

Individual glycoalkaloids were characterized by TLC on silica gel using the lower phase of $\mathrm{MeOH}-\mathrm{CHCl}_{3}(1: 1)$ saturated with 0.5 parts of $1 \% \mathrm{NH}_{4} \mathrm{OH}$. Comparisons were made with standard compounds. Aglycones of total precipitates were obtained as described previously [14]. Aglycones were characterized by TLC on silica gel using $\mathrm{CHCl}_{3}-\mathrm{MeOH}(97: 3)$ and by $\mathrm{GLC}$ as described previously [15]. Ambiguities between pairs of saturated and unsaturated aglycones were resolved by the differential hydrolysis method of Osman and Sinden [14]. Where possible aglycones were quantified using a Hewlett-Packard 3390A Integrator.

Where identities of glycoalkaloids remained ambiguous compounds were purified by preparative TLC. Aglycones were identified using the methods described above or by GC/Ms using a 20m OV-101 capillary column. The column was temperature programmed from 150 to $250^{\circ}$ at $4^{\circ}$ per min. Total glycoalkaloids were determined using a titration method [16].

Acknowledgements-This research was supported by financial assistance to T.J. from the Natural Sciences and Engineering Research Council Canada (Postgraduate Scholarship), the National Science Foundation (Dissertation Grant \# DEB-8208298) and the International Board of Plant Genetic Resources, Rome. We thank Z. Huamán, P. E. Schmiediche and C. M. Ochoa (International Potato Center (CIP), Lima), I. Avilez (IBTA, Bolivia), R. E. Hanneman (Potato Introduction Station, Sturgeon Bay), M. M. Martin, G. M. Hatfield, R. I. Ford and S. L. Keen for their assistance.

\section{References}

1. Hawkes, J. G. and Hjerting, J. P. (1969) The Potatoes of Argentina, Paraguay and Uruguay. Clarendon, Oxford.

2. Huamán, Z., Hawkes, J. G. and Rowe, P. R. (1980) Econ. Botany 34, 335.

3. Hawkes, J. G. (1954) J. d'Agric. Tropicale et de Botanique Appliquee 7-9, 356.

4. Hawkes, J. G. (1972) Symp. Biol. Hung. 12, 65.

5. Correll, D. S. (1962) The Potato and its Wild Relatives. Texas Research Foundation, Renner, Texas.

6. Gregory, P. (1984) Am. Potato J. 61, 115.

7. Osman, S. F., Herb, S. F., Fitzpatrick, T. J. and Schmiediche, P. (1978) J. Agric. Food Chem. 26, 1246.

8. Schrieber, K. (1968) Alkaloids 10, 1.

9. Gregory, P., Sinden, S. L., Osman, S. F., Tingey, W. M. and Chessin, D. A. (1981) J. Agric. Food Chem. 29, 1212.

10. Ochoa, C. (1984) Phytologia 55, 17.

11. Johns, T. A. (1985) Chemical Ecology of the Aymara of Western Bolivia: Selection for Glycoalkaloids in the Solanum $\times$ Ajanhuiri Domestication Complex. Ph.D. Dissertation, University of Michigan, Ann Arbor.

12. Huamán, Z., Hawkes, J. G. and Rowe, P. R. (1982) Euphytica 31, 665.

13. Osman, S. F., Johns, T. and Price, K. (1986) Phytochemistry $25,967$.

14. Osman, S. F. and Sinden, S. L. (1977) J. Agric. Food Chem. 25, 955.

15. Sinden, S. L., Sanford, L. L. and Osman, S. F. (1980) Am. Potato J. 57, 331.

16. Fitzpatrick, T. J. and Osman, S. F. (1974) Am. Potato J. 51, 318. 